\title{
Research on the Actual Effect of Ideological and Political Education in Colleges under the New Media Environment
}

\author{
Qiuli Gao \\ NanChang Institute of Science \& Technology, Nanchang, 330108
}

Keywords: New media; Colleges; Ideological and political education; Effectiveness

\begin{abstract}
With the progress of science and technology, today's society has entered the new media era. In the real society with information media as the link, the rapid development of new media technology provides a great convenience for people to obtain information, at the same time, the new media as an effective subtle ideological and political education, have a very important role and influence on the ideological ideas of college students, the formation and development of moral ideology, political consciousness, of value judgments have great function and impact. New media, the double-edged sword bring ideological and political education to facilitate the college students, but also the ideological and political education of college students posed a great challenge. This article mainly do up and definite the relevant concepts and characteristics, performance and other aspects on the effectiveness ideological and political education under the new media environment.
\end{abstract}

\section{Introduction}

Every time the development of science and technology will bring new advances in communication technology, new media under the support of the emergence by the new technology, as a new way of information dissemination, has been more and more into our lives, it not only runs through the whole economic, political and cultural activities, but also profoundly affect our world outlook, outlook on life and values. College students as the most active group of ideas, although they have certain things or information on the outside world to determine the criteria and trade-offs, but in the new media environment, some college students will lose the value of the standard, resulting in ideological confusion and moral deficiencies, thus causing the behavior of the runaway. How to make full use of various new media and enhance the effectiveness of ideological and political education of college students is an important subject to be solved urgently by the ideological and political education workers in the face of the active group of college students. This article is in this context, taking the practical effect of the ideological and political education of college students under the new media environment under as the object of study, by analyzing the impact of new media on the effectiveness of ideological and political education of college students, and then put forward countermeasures, hoping to strengthen the ideological and political education of college students.

\section{The Characteristics of the Actual Effect of Ideological and Political Education of College Students}

The Effectiveness of the Time Lag. Ideological and political education of college students is a process, and is an extremely complex process. From the received information of ideological and political education to accept their own information, and then to transfer these information into their own inner beliefs, and then integrate these beliefs into their words and deeds is a continuous process, in the process of this process need to takes a long time, that is, the effect will be very slow, will not soon see the effect, often after the impact of education in a period of time to see the educational effect, which is subject to many aspects of the combined effect of the results, because the habit formation is also a process, so it need to take a long time to develop good habits in this process.

The Diversity of Effective Forms of Performance. The manifestation of the effectiveness of ideological and political education of college students is varied, and this kind of performance can be embodied in the behavior of college students, and can also be reflected in their changing emotions. 
Their behavior can be directly or indirectly reflect the effectiveness of ideological and political education of college students. Although some students accept the content and requirements of education, but they will not show it obviously, but internalization in the heart, to obey this education standards in their heart.

Affecting the Universality of Effectiveness Factors. The ideological and political education work of college students is a complicated and systematic project, and the process is affected by the comprehensive influence of various factors from society. These factors affect their ideological and political education from different perspectives, different levels, different times, different places, and still play their different roles in different environments. To improve the effectiveness of ideological and political education of college students, it is necessary to carry out a comprehensive, in-depth and detailed analysis of the impact of these aspects, only comprehensively analyzing the proposed countermeasures it can be more specific and targeted, far away from the analysis of various factors on the impact of the specific requirements, We can not achieve good ideological and political education effect, the ideological and political education of the effectiveness of college students can not be improved accordingly.

\section{The Problems in the Application of New Media in the Ideological and Political Education of College Students}

As the current regulatory mechanism for new media is not yet sound, teachers and students of the media literacy is not high, and the lack of timely and correct guidance and supervision on some hot and other issues, the effective use of new media in college students ideological and political education exist a lot of problems. In the new media environment, the improvement of the ideological and political education of college students depends on the improvement of these problems, the main problems through the author's comprehensive induction of new media in the ideological and political education of college students are as the following aspects:

Guidance and Management is not Enough. New media this new thing, its role in the education can not be separated from its guidance and management, but in the actual work, due to the new media regulatory mechanism is not yet sound and some teachers unfamiliar with new media, they will not use the new media for class, resulting in the role of new media did not get a better play, but also under certain conditions and even give our education and teaching work to bring resistance or negative impact, which will make education activities deviate from the ultimate goal of ideological and political education.

Prone to Formalism of the Drawbacks. New media is the media form under the new technical support system, an effective tool can be used for college students ideological and political education. But in real life, sometimes the use of new media will appear the drawbacks of formalism of, can not play its ideological and political education function. Such as some of the schools website of ideological and political education for college students almost no one visit or very few people to visit, so these sites have become a lot of schools to follow suit or to answer the "check", do not play the proper education effect, and later may evolve into the form, go through the field, can not reach the ideological and political education purposes.

Vulnerable to the Impact of Adverse Social Atmosphere. In the context of globalization, because the new media with the features that interactive and real-time, mass and sharing, the spread of barrier-free, which makes it easy to make a variety of foreign negative decay ideas into the university campus, so that students is easy to be influenced by bad social atmosphere, and it is easy to induce all kinds of bad thoughts tendencies among them, such as liberalism, decentralism and money worship, hedonism and egoism.

\section{The Countermeasure of Improving the Effectiveness of the Ideological and Political Education under the New Media Environment}

Update the Ideological and Political Education Concept of College Students. The educational concept of the workers of ideological and political education should be combined with the concept 
of new media, to find common ground in the combination of the two sides, learn to actively use new media, enhance the use of new media technology skills, skillfully use new media in the class. Only with the advanced ideological and political education and the concept, new media can be applied to practice, through the better use of new media to carry out ideological and political education of college students, to achieve the best educational results, to promote college students to improve the level of ideological and moral.

Innovative Ideological and Political Education Content of College Students. Under the new media environment, ideas of college students are more trendy, the ability to accept and understand new things is strong, so in the choice of educational content, should choose content close to their actual content of life. If the educational content is too remote, too out of their lives, then the education effect is certainly not very good, and may even play the opposite role. The purpose of ideological and political education is to promote good moral behavior and habits of college students, so that they can consciously resist the bad temptation, away from their own harm to things.

Strengthen the Ideological and Political Education Team Construction. The impact of the new media environment on the ideological and political education of college students is huge, which is largely related to the low quality of new media practitioners, it is necessary to improve the overall quality of new media practitioners to start strengthen the construction of ideological and political education for college students.

\section{Conclusion}

Ideological and political education is an important part of ideological work, playing a significant role in the construction of superstructure and economic foundation. Especially in the background of the rapid development of science and technology, new media constantly updated, the ideological and political education workers should pay attention to the use of advanced media, and actively respond to the opportunities and challenges brought about by the effectiveness of traditional ideological and political education under the new media environment to explore new ways to enhance the effectiveness of ideological and political education of college students. In the face of the advantages and disadvantages of the new media environment, the state, society, schools and families should bear their respective responsibilities, avoid weaknesses and take effective measures to reduce the negative impact of the new media environment as much as possible, creating the new media environment for students so that they grow up in this new era of healthy media.

\section{References}

[1] Tang Y. The Research on university ideological and political education based on set pair analysis and inter-subjectivity [J]. Advances in Information Sciences \& Service Sciences, 2012, 4(20):198-205.

[2] Wang H J. Challenges of mobile internet to university ideological and political education and the countermeasures [J]. Journal of Jiangxi Blue Sky University, 2011.

[3] Wei M. Analysis of university ideological and political education under internet culture[J]. Journal of Nanjing University of Finance \& Economics, 2008.

[4] Jing L I. Research on quality optimization of university ideological and political education teachers[J]. Teacher Education Forum, 2016.

[5] Zhang M Z, Lan H S. The Development and innovation of university ideological and political education in the Perspective of Risk Society [J]. Journal of Fujian Commercial College, 2016.

[6] Wei X W, Xiao-Hong L I, Marxism S O. Study of the communication effects of university ideological and political education in new media environment [J]. Journal of Dalian University of Technology, 2015.

[7] Liu Y. Study on the necessity of apartment counselors in university ideological and political Education Work [J]. Journal of Jiamusi Vocational Institute, 2015. 
[8] Zhang L. Research on effective approaches for setback education in university ideological and political education [J]. Science Education Article Collects, 2015.

[9] Che L, Liu Y, Jiang S. Exploration on the application of agenda-setting theory in the ideological and political education of university students [J]. Science Education Article Collects, 2016, 87(2):195-200.

[10] Hong-You L I, University S. situation and reflection of university's network ideological and political education in China [J]. Journal of University of Electronic Science \& Technology of China, 2016.

[11] Xie A L. The approach innovation of ideological and political education in university under the new media environment $[\mathrm{J}]$. Journal of Jilin Teachers Institute of Engineering \& Technology, 2016.

[12] Xu S. Research on ideological and political education of southwest petroleum university students in micro blog era [J]. Creative Education, 2016, 7(2):287-292. 